\title{
Exogenous Calcium Fibrin Sealant Loaded with Ageratum conyzoides Linn. Bactericidal Plant Extract: Equilibrium between a Biochemical Activator and Phytochemicals Inhibitors of Thrombin
}

\author{
*Akpalo A.E. ${ }^{\text {, }}$, Douti F.V. ${ }^{1}$, Layibo Y. ${ }^{2}$, Awaga K.L. ${ }^{1}$, Feteke L. ${ }^{3}$, Karou D.S. ${ }^{1}$
}

\begin{abstract}
Objective: It is of primary importance to develop wound healing sealant that prevent bacteria contamination and growth. We propose to formulate poor platelets plasma material supplemented with a bactericidal plant extract, Ageratum conyzoides Linn. (Asteraceae). Aqueous extract of this plant is used as a bactericide.

Methodology: Platelet-poor plasma (PPP) containing less than 10,000 platelets per $\mu \mathrm{L}$ were used for all experimentations. Physiological serum $(\mathrm{NaCl} 0.9 \%)$ had served to prepare calcium chloride $\left(\mathrm{CaCl}_{2}\right)$ solutions at $2 \mathrm{M}, 4 \mathrm{M}, 6 \mathrm{M}, 8 \mathrm{M}$ and $10 \mathrm{M}$. Clauss fibrinogen assays were done to determine fibrinogen concentrations in each plasma pocket. Clotting times were measured following the addition of the appropriate calcium chloride concentration to the plasma. Plant extract at a concentration of $250 \mathrm{mg} / \mathrm{mL}$ in physiological serum was also added to the plasma and followed by the clotting times measured.
\end{abstract}

Results: Clauss fibrinogen assays reflected a global satisfactory fibrinogen concentration. Overall profile of the evolution of clotting time $v s$ calcium concentrations adopts a curve form and the shortest clotting times are those obtained with $4 \mathrm{M}$ calcium concentration. However, the presence of extract deeply disturbed clotting process, as clotting times were extremely elongated.

Conclusion: Our objective was difficult to achieve because of the thrombin inhibitory side effects of the extract which were added to antithrombin III inhibitory effects in presence of excess calcium.

Keywords: Wound healing, fibrin sealant, Ageratum conyzoides Linn., biomaterial, inhibitors.

\author{
*Corresponding Author \\ Akpalo A.E. \\ http://orcid.org/0000-0003-4940-5554 \\ E-mail: edefia@gmail.com \\ ${ }^{1}$ University of Lome, Department of Biochemistry \\ ${ }^{2}$ National Institute of Hygiene, Department of Hematology \\ ${ }^{3}$ Blood Transfusion National Center
}




\title{
ORIGINAL ARTICLE
}

\section{Formation d'un Biomatériau de Fibrine par Apport Exogène de Calcium et Supplémentation par un Extrait Bactéricide de la plante Ageratum conyzoides Linn. : Equilibre entre un Activateur Biochimique et des Inhibiteurs Phytochimiques de la Thrombine}

\author{
*Akpalo A.E. ${ }^{1}$, Douti F.V. ${ }^{1}$, Layibo Y. ${ }^{2}$, Awaga K.L. ${ }^{1}$, Feteke L. ${ }^{3}$, Karou D.S. ${ }^{1}$ \\ RÉSUMÉ \\ Objectif: Il est d'une importance capitale de développer des pansements cicatrisants qui empêchent la \\ contamination et la prolifération bactérienne. Nous nous proposons de formuler un biomatériau cicatrisant de \\ fibrine à base de plasma pauvres en plaquettes et supplémenté d'un extrait aqueux de Ageratum conyzoides Linn.
}

Méthodes: Du plasma pauvre en plaquettes contenant moins de 10000 plaquettes par $\mu \mathrm{L}$ a été utilisé pour toutes les expérimentations. Le sérum physiologique $(\mathrm{NaCl} 0,9 \%)$ a servi à la préparation des différentes solutions de calcium aux concentrations de $2 \mathrm{M}, 4 \mathrm{M}, 6 \mathrm{M}, 8 \mathrm{M}$ et $10 \mathrm{M}$. Le dosage du fibrinogène par les tests de Clauss a été effectué pour chaque poche de plasma. Les temps de gel ont été déterminés suite à l'addition du calcium à la concentration adéquate. L'extrait de plante à la concentration de $250 \mathrm{mg} / \mathrm{mL}$ dans du sérum physiologique a également été additionné au plasma suivi de la détermination des temps de gel.

Résultats: Les tests de Clauss mènent à des taux de fibrinogène moyens satisfaisants. Le profil global de l'évolution des temp de gel en fonction de la concentration en calcium adopte une forme hyperbolique et le temps le plus court est obtenu à 4M de calcium. La présence de l'extrait perturbe profondément la formation du gel puisque les temps de gel de ces derniers sont extrêmement rallongés.

Conclusion: Notre objectif a été difficile à atteindre à cause des effets secondaires inhibiteurs de l'extrait qui se sont ajoutés à ceux de l'antithrombin III en présence d'un excès de calcium.

Mots clé: Cicatrisation ; Pansement fibrine ; Ageratum conyzoides Linn. ; Activateur; Inhibiteurs.

\author{
*Corresponding Author \\ Akpalo A.E. \\ http://orcid.org/0000-0003-4940-5554 \\ E-mail: edefia@gmail.com \\ ${ }^{1}$ University of Lome, Department of Biochemistry \\ ${ }^{2}$ National Institute of Hygiene, Department of Hematology \\ ${ }^{3}$ Blood Transfusion National Center
}




\section{INTRODUCTION}

Fibrin sealant contains concentrated fibrinogen and thrombin as its main active substrate and enzyme, and is usually mixed in the presence of calcium chloride, which speeds up fibrin polymerization (1). Ionic conditions, numerous endogenous and exogenous compounds, medications, as well as albumin, fibronectin, lipoprotein(a), and other normal and pathological proteins present in plasma and injured tissues, influence clot structure formation (2). One of the simplest methods for modifying fibrin structure is to vary the concentration of proteins, calcium, or salt present during polymerization(3).

Fibrin's high degree of tunability make it a versatile biomaterial that is used in a wide range of applications to facilitate wound repair, tissue engineering and regeneration, and biologics delivery (3). Fibrin is an appealing drug delivery vehicle because it can be injected where it gels in situ, it is naturally degraded and it stimulates the body's own wound healing response (4).

Fibrin can also serve as a delivery vehicle for antimicrobial agents to prevent infection at the wound site (3). Fibrin sealant can be used at the specific targeted site such as chemotherapeutic agents vehicle and antibiotics or hormones like the healing growth factors vehicle. In these cases, fibrinolysis governs the rate of drug or hormone release from the fibrin vehicle(5) on the wound site.

During the formation of the hemostatic plug, adhesive glycoproteins from plasma become incorporated into the fibrin clot by covalent crosslinking providing a scaffold for cell migration and proliferation (6). The major role of plasma complement present in various platelet biomaterials derived from platelets-rich plasma in inactivating gram-negative E. coli, Klebsiella pneumonia, and Pseudomonas aeruginosa was demonstrated(1).

However, working with poor platelets plasma (PPP), means working in absence of platelets, allowing growth factors and plasma proteins (fibrinogen, fibronectin) rich environment, without cellular biomaterials conservation troubles and difficulties (cryoprecipitation, limit of conservation time). Then, we propose to formulate poor platelets plasma (PPP) material supplemented with a bactericidal plant extract to retrieve biological and biochemical wound healing properties of a platelet rich plasma (PRP).

Bacterial infections are a serious problem in wound healing and they impair tissue regeneration and contribute to chronic non-healing states (1). The Word Health Organization advocated that countries should interact with traditional medicine in the aim to identify and explore aspects that provide safe and effective remedies for ailments of both microbial and non-microbial origins (7). The use of herbal preparations containing high doses of flavonoids for health maintenance has become very popular (8). Phytochemicals have exhibited potent activities while many researchers have used natural products to act against bacterial resistance (9) and the relationship between the structure of natural compounds and their possible mechanism of action was established.

Ageratum conyzoides Linn. (Asteraceae) is an annual herb in the tropics and subtropics whose extracts are known to possess pharmacological and biological activity (10). The mature plant is used for its hemostatic, and anti-inflammatory properties for the treatment of wounds in bacterial infections (11).

Various extracts of the plant, including water and methanol have been shown to inhibit the growth of Staphylococcus aureus, Bacillus subtilis, Escherichia coli, Pseudomonas aeruginosa and Helicobacter pylori (10). Aqueous extract of this plant is used as a bactericide (12).

Then, we propose to formulate poor platelets plasma (PPP) material supplemented with the bactericide Ageratum conyzoides Linn. (Asteraceae) aqueous extract.

\section{MATERIALS AND METHODS}

\section{Biological materials}

\section{Plasma}

The plasma for the study was obtained from the National Center of Blood Transfusion (Centre National de Transfusion Sanguine - CNTS). After different stages and types of control and individual donor plasma obtained, the National Center of Blood Transfusion (Centre National de Transfusion Sanguine - CNTS) placed the plasma pockets at public disposal. They used CDPA-1 double blood bag to supply citrated plasma.

All tests were conducted on healthy random population samples. To achieve this experiment, fifteen (15) platelet-poor plasma (PPP) pockets containing less than 10,000 platelets per $\mu \mathrm{L}$ were used.

Ethical approval was obtained from the Institutional Committee of the National Center of 
Blood Transfusion (Centre National de Transfusion Sanguine-CNTS).

\section{Physiological serum solutions}

$500 \mathrm{~mL}$ sodium chloride solution or physiological serum $\left(\mathrm{NaCl} 0.9 \%\right.$ ) bottles (Batch $\mathrm{N}^{\circ}:$ 1801021) from DO-PHARMA were used. Calcium chloride $\left(\mathrm{CaCl}_{2}\right)$ (Batch $\mathrm{N}^{\circ}$ : 07/240028) was purchased from VWR International and had served to prepare solutions at 2 , 4, 6, 8 and 10 molars when dissolved in physiological serum $(\mathrm{NaCl} 0.9 \%)$. This sodium saline was used as it is isotonic with the plasma.

\section{Clotting time measures}

For clotting time measures, coagulometer START4 (Diagnostica Stago) was used. Plasma samples were aliquoted at a volume of $990 \mu \mathrm{L}, 890 \mu \mathrm{L}$ or $800 \mu \mathrm{L}$ and stored at $-20^{\circ} \mathrm{C}$ for a week at the most. To start the clotting times assays, each aliquot was warmed at $37^{\circ} \mathrm{C}$ in a waterbath for 15 minutes, then $10 \mu \mathrm{L}$ of the correspondent calcium chloride concentration were added to the $990 \mu \mathrm{L}$ plasma aliquots. $890 \mu \mathrm{L}$ plasma aliquots were added with $100 \mu \mathrm{L}$ of physiological serum followed by $10 \mu \mathrm{L}$ of the correspondent calcium chloride concentration. $800 \mu \mathrm{L}$ plasma aliquots were added with $100 \mu \mathrm{L}$ of physiological serum or $100 \mu \mathrm{L}$ of $250 \mathrm{mg} / \mathrm{mL}$ extract in physiological serum. Both mixings were completed with $90 \mu \mathrm{L}$ of physiological serum followed with 10 $\mu \mathrm{L}$ of the correspondent calcium chloride concentration. Just after calcium chloride addition, the chronometer was instantaneously triggered and the mixture homogenized. The limiting clotting time imposed for our experimental method was 2 hours (120 minutes or 7200 seconds). For each calcium chloride concentration, clotting time measurements were done in triplicate. For each calcium chloride concentration, clotting time measurements were done in triplicate. We measured each sample clotting time three times for repeatability of the method leading to a total of fifteen (15) or nine (9) assays for five (05) or three (03) samples instead of testing fifteen (15) or nine (09) donors' plasma samples.

\section{Clauss fibrinogen assay}

Fibri-Prest $^{\circledR}$ Automate (Réf. 00613), STA ${ }^{\circledR}$-OwrenKoller (Réf. 00360), Unicalibrator (Réf. 00625), Coag Control N + P (Réf. 00621) were used to determine fibrinogen concentration in each plasma pocket. Fibrinogen concentration was expressed in $\mathrm{g} / \mathrm{L}$ or $\mathrm{mg} / \mathrm{dL}$. All the tests were done in triplicate and the results were expressed as mean.

\section{Plant materials}

\section{Ageratum conyzoides Linn.}

The plant samples were collected in the beginning of the raining period in May 2019 in Guerin kouka (GPS coordinates: $9.6896200 ; 0.6079700)$ situated in the Kara region in Northern Togo.

Vegetable sample was botanically authenticated by Dr Atakpama of the Department of Botanic as " $\mathrm{E}$ $9^{\circ} 41^{\prime 22} .6^{\prime \prime} \mathrm{N} 0^{\circ} 36 ' 28.7^{\prime \prime}$ University of Lome from the National Forest Inventory of Togo database (IFN 2015). The fresh material was oven-dried at a temperature not exceeding $37^{\circ} \mathrm{C}$ for a week.

\section{Extraction}

To prepare plant extracts, the method, although greatly modified, was inspired from (Li et al., 2011). The dried leaves of the plant finely cut $(25 \mathrm{~g}$ in weight) were extracted with distilled water $(250 \mathrm{ml})$ : $3 \mathrm{~h}$ at $50{ }^{\circ} \mathrm{C} \pm 2{ }^{\circ} \mathrm{C}$. Thereafter, the extracts were weighted and a certain amount of $95 \%$ ethanol was added. The final concentration of extracts solution was obtained by dilution to $80 \%$. This extract solution was deposited overnight at RT $\left(25^{\circ} \mathrm{C} \pm 2{ }^{\circ} \mathrm{C}\right)$ and centrifuged at $4000 \mathrm{rpm}$ for $10 \mathrm{~min}$. The mixture was filtered and the filtrate was dried. The clear residue was dissolved in a sodium saline solution at a concentration of $250 \mathrm{mg} / \mathrm{mL}$ and used for biochemical studies.

\section{Statistical analysis}

All clotting time results were analyzed by the Student test (14). The 95\%-confidence interval $(95 \%$-CI) for the percentage change at every time point was calculated. Statistical significance was assumed for $p$-value $<0.05$.

\section{RESULTS}

\section{Clauss assays}

A number of methods are used to determine fibrinogen concentration in plasma, and the widely used method is the functional fibrinogen assay according to Clauss (15).

In Table I, sixty per cent $(60 \%)$ of plasma pockets corresponding to $9 / 15$ of donors, have fibrinogen concentration belongs to the recommended international interval. Others $40 \%$ fibrinogen concentration are not so far from the lower limit. Considering all the donors are safe, these results reflect a global satisfactory fibrinogen concentration. 


\section{Clotting time measures}

In a previous work (14), we established an approved statistical method which is very helpful to determine mean clotting times to obtain plasma fibrin sealant by only adding $\mathrm{CaCl}_{2}$. In this experiment, we use the same method to determine not diluted plasma, physiological serum diluted and extract added to plasma, fibrin clotting times.

All mean clotting times obtained for not diluted plasma and physiological serum diluted plasma are presented in Table II and represented in Figure 1.

Clotting time mean variation after plasma dilution (9/10th) with physiological serum is above 0.5 ; all clotting times from $2 \mathrm{M}$ to $8 \mathrm{M}$ calcium concentrations were divided by 2 when plasma was diluted at $90 \%$.

Figure 1 shows overall profile of the evolution of clotting time vs calcium concentrations adopts a curve form. The shortest clotting times in the two cases (not diluted and diluted plasma) are those obtained with $4 \mathrm{M}$ calcium concentration mixing with plasma at $37^{\circ} \mathrm{C}$. We have already shown that no gelation occurred at $0 \mathrm{M}$ and $10 \mathrm{M}$.
When dilution attempted $80 \%$, clotting times reincreased. This was certainly due to fibrinogen concentration lowering with dilution. However, the lowerest clotting time was obtained at $4 \mathrm{M}$ calcium concentration ( $11 \pm 4.15$ minutes) and stayed lower than clotting time of not diluted plasma $(13 \pm 1.57$ minutes).

The previous established and approved statistical method (14) was also used to determine plant extracts diluted (Table III) plasma mean clotting times.

These results could not be statistically interpreted since clotting time $>7200$ seconds are not taken into account or are considered as no clotting. We obtained only one tc value at $2 \mathrm{M}$ calcium and no one at $4 \mathrm{M}$ calcium. Then they are not statistically representative. Overall observation is that presence of extract deeply disturbs clotting process as we obtained no gelation at $6 \mathrm{M}, 8 \mathrm{M}$ and $10 \mathrm{M}$.

At $2 \mathrm{M}$ calcium, not diluted plasma had a clotting time value of $22 \pm 3.81$ minutes; physiological serum diluted plasma $(9 / 10)$ had a clotting time value of $11 \pm$ 0.68 minutes and $250 \mathrm{mg}$ extract diluted plasma had a clotting time value of $65 \pm 12.56$ minutes.

Table 1: Clauss estimation of mean fibrinogen concentration in the fifteen donors' pockets

\begin{tabular}{llll}
\hline Donors & Blood group & {$[\mathbf{F g}] \mathbf{~} \mathbf{g} / \mathbf{m L}$} & $\mathbf{C}[\mathbf{2} ; \mathbf{6}] \mathbf{g} / \mathbf{L}$ \\
\hline 1 & $\mathrm{O}^{-}$ & 1,77 & No \\
2 & $\mathrm{O}^{-}$ & 2,6 & Yes \\
3 & $\mathrm{O}^{+}$ & 1,8 & No \\
4 & $\mathrm{O}^{+}$ & 2,5 & Yes \\
5 & $\mathrm{~A}^{+}$ & 1,87 & No \\
6 & $\mathrm{~B}^{+}$ & 3,5 & Yes \\
7 & $\mathrm{~A}^{+}$ & 2,1 & Yes \\
8 & $\mathrm{AB}^{+}$ & 1,8 & No \\
9 & $\mathrm{~B}^{+}$ & 1,8 & No \\
10 & $\mathrm{~A}^{+}$ & 1,73 & No \\
11 & $\mathrm{O}^{+}$ & 2 & Yes \\
12 & $\mathrm{O}^{+}$ & 2,77 & Yes \\
13 & $\mathrm{~A}^{+}$ & 2,23 & Yes \\
14 & $\mathrm{O}^{+}$ & 2,07 & Yes \\
15 & $\mathrm{~A}^{+}$ & 2,17 & Yes \\
\hline
\end{tabular}

$(2 ; 6)$ is the recommended international interval for plasma fibrinogen concentration.

Table 2: Clotting times of not diluted $(990 \mu \mathrm{L}$ plasma) and diluted plasma $(890 \mu \mathrm{L}$ plasma) vs chloride calcium concentrations

\begin{tabular}{ccc}
\hline (CaCl2) & $\begin{array}{c}\text { Clotting time (min) } \\
\text { Not diuted Plasma }\end{array}$ & $\begin{array}{c}\text { Clotting time (min) } \\
\text { Diluted Plasma }\end{array}$ \\
\hline $0 \mathrm{M}$ & $>120$ & $>120$ \\
$2 \mathrm{M}$ & $22 \pm 3,81$ & $11 \pm 0,6$ \\
$4 \mathrm{M}$ & $13 \pm 1,57$ & $6 \pm 3,64$ \\
$6 \mathrm{M}$ & $19 \pm 6,53$ & $13 \pm 2,13$ \\
$8 \mathrm{M}$ & $35 \pm 29,3$ & $17 \pm 9$ \\
$10 \mathrm{M}$ & $>120$ & $>120$ \\
\hline
\end{tabular}




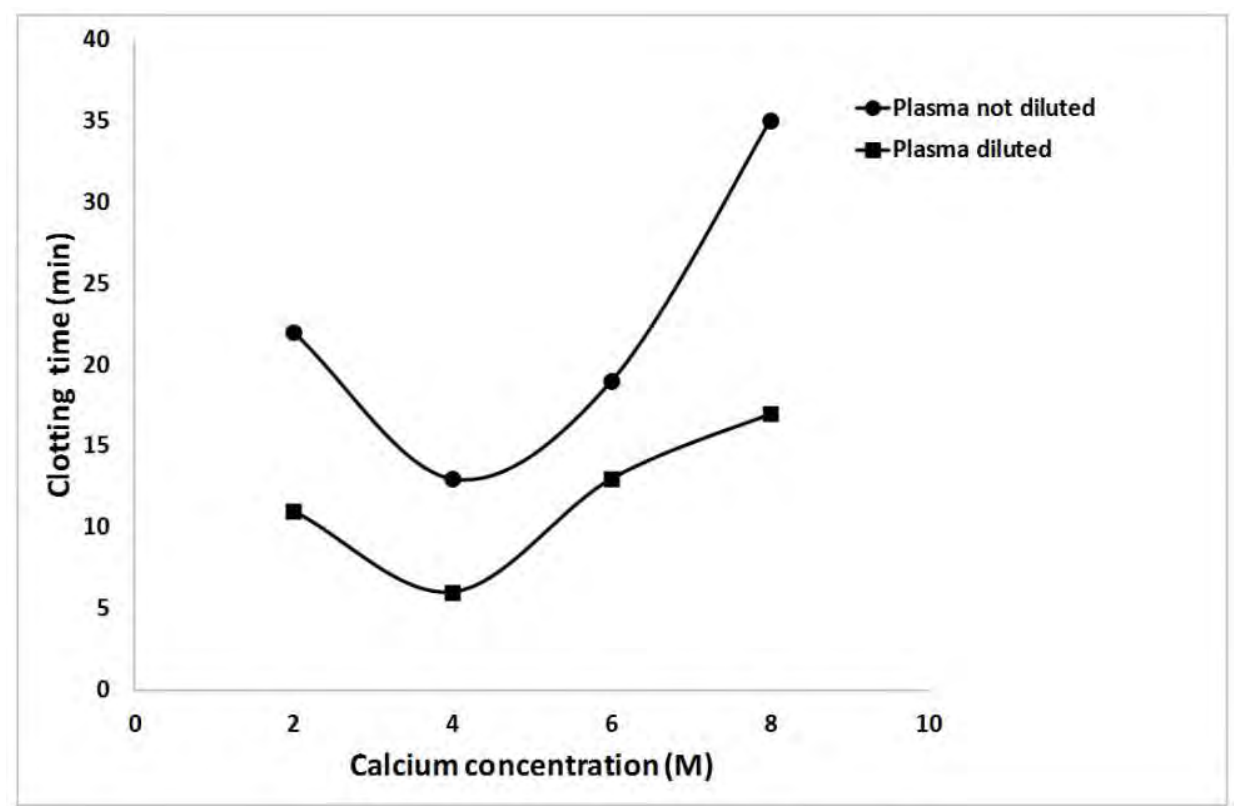

Figure 1: Clotting times of not diluted and diluted plasma vs chloride calcium concentrations

Table 3: Clotting time measures of plant extracts diluted plasma

\begin{tabular}{|c|c|c|c|c|}
\hline $\begin{array}{l}\text { Calcium concentration } \\
\left(\mathrm{CaCl}_{2}\right)(\mathrm{M})\end{array}$ & $2 \mathrm{M}$ & $4 M$ & $6 \mathrm{M}$ & $8 \mathrm{M}$ \\
\hline Donors groups & $\mathrm{A}^{+} ; \mathrm{O}^{+} ; \mathrm{A}^{+}$ & $\mathrm{A}^{+} ; \mathrm{O}^{+} ; \mathrm{A}^{+}$ & $\mathrm{A}^{+} ; \mathrm{O}^{+} ; \mathrm{A}^{+}$ & $\mathrm{A}^{+} ; \mathrm{O}^{+} ; \mathrm{A}^{+}$ \\
\hline Effectif (N) & 3 & 3 & 3 & 3 \\
\hline Clotting times & $>7200$ & $>7200$ & $>7200$ & $>7200$ \\
\hline \multirow[t]{2}{*}{ Variables $\mathrm{x}_{1}$} & 3553 & 5298 & $>7200$ & $>7200$ \\
\hline & $>7200$ & $>7200$ & $>7200$ & $>7200$ \\
\hline Clotting times & 4110 & 5296 & $>7200$ & $>7200$ \\
\hline \multirow[t]{2}{*}{ Variables $x_{2}$} & 4510 & $>7200$ & $>7200$ & $>7200$ \\
\hline & 5764 & $>7200$ & $>7200$ & $>7200$ \\
\hline Clotting times & 3726 & 5727 & $>7200$ & $>7200$ \\
\hline \multirow{2}{*}{ Variables $x_{3}$} & 5148 & $>7200$ & $>7200$ & $>7200$ \\
\hline & 2165 & $>7200$ & $>7200$ & $>7200$ \\
\hline $\begin{array}{l}\text { Mean clotting time } \\
\pm \text { CI }\end{array}$ & $\begin{array}{l}65 \pm 12.56 \\
\text { minutes }\end{array}$ & $\begin{array}{l}92 \pm 14.10 \\
\text { minutes }\end{array}$ & minutes & minutes \\
\hline
\end{tabular}

\section{DISCUSSION}

Table 1 shows Clauss estimation of mean fibrinogen concentration in the fifteen donors' plasma pockets. A first analysis leads to sixty per cent $(60 \%)$ of plasma pockets, corresponding to $9 / 15$ of donors, who have fibrinogen concentration belongs to the recommended international interval. Referring to our previous work (14), the third comprehensive way to explain variable clotting times obtained, was the possible high-hematocrit collected blood leading to excessive citrate concentration, resulting in elongated clotting time (meaning weak fibrinogen concentration). According to this, the $40 \%$ of fibrinogen concentration which do not belong to the recommended international interval but are very near to $2 \mathrm{mg} / \mathrm{mL}$, the lower limit fibrinogen concentration, would not be systematically attributed to pathologic donors or dysfibrinogenemia cases. Then, all given results were accepted.

Gelation dynamics induced by polymer solutions and crosslinkers have been studied for a long time. Most studies were conducted under mixing or agitation such as by stirring the solution to form an isotropic gel, since the gelation occurs homogeneously in the reaction system (16). In this study, experimental clotting times were noted when the movement of the ball stirring the sample solution stopped.

A multitude of parameters influence fibrin polymerization rates and resulting fiber structure including ionic strength, protein and zymogen concentrations, calcium concentration, and $\mathrm{pH}$ (17). 
There are correlations between gel time and final clot structure, but the complete network is generally not established at the gel point, with new fibers and branchpoints still being established afterward (2). This phenomenon is explained by the fact that thrombin is a processive enzyme.

In our previous work (14), three comprehensive ways of plasma clotting time by adding exclusively exogenous calcium were identified. Among them, interaction of calcium with citrate in citrated plasma leading to activation of prothrombin to thrombin (16). In the present work, $9 / 10^{\text {th }}$ dilution of plasma corresponds to less citrate needing calcium interaction, then quicker activation of prothrombin to thrombin was observed. This resulted in shorter clotting times (Table 2 ). We could hardly suppose that sodium monovalent cations of sodium chloride present in physiological serum also interact with citrate like calcium divalent cations.

Based on their chemical structures, plant components can be classified into alkaloids, sulfurcontaining compounds, terpenoids and polyphenols (9). The largest and best known group among the polyphenolic compounds are flavonoids -(18). In a previous work, we have demonstrated that Ageratum conyzoides Linn. aqueous leaves extract $\left(50^{\circ} \mathrm{C}-3 \mathrm{H}\right)$, the extract we used in this study, contained several types of flavonoids (19).

Plant-derived compounds have displayed more potential applications in combating bacterial infections (9). The antibacterial activity of flavonoids has a positive correlation with their ability to rigidify the E. coli membrane (9). Flavonoids contained in Ageratum conyzoides Linn. show antibacterial activity; this could be related to their ability to form complex connections with extracellular, soluble proteins, and bacterial cell walls (20).

This extract contains proanthocyanidins and their monomers catechins (19). The catechin gallates such as epigallocatechin gallate (EGCG) are another group of phenolic compounds that provide health benefits and also exhibited potent antimicrobial activity against resistant pathogens (9). Tannins cause antimicrobial action by precipitating microbial proteins. The potency depends on their concentration in the plants (20).

Almost $50 \%$ of triterpenes were identified in our used extract (19) and terpenes or isoprenoids are considered as the most diverse family of natural products (9). As antimicrobial molecules, terpenes have an effect on cytoplasm coagulation, membranes proteins, cell wall and efflux pumps. The antimicrobial mechanism of terpenes is closely associated with their lipophilic features. Monoterpenes impact on the structures of the membrane, altering the topology of its proteins and making disturbances across the respiration chain (9). Commonly, Gram-positive bacteria are more sensible to terpenes than Gram-negative ones.

We also have identified the presence of stigmasterol, an analgesic (21), a triterpenoid and phylloquinol which is known as vitamin $\mathrm{K} 1$ required for prothrombin formation. Three chromenes structures were also identified (20). The length of the hydrocarbon chain connected to the hydroxyl group (aricjournal.biomedcentral.com) of various terpene alcohols, plays an important role in antibacterial and cell membrane disrupting activity (9). Essential oil of Ageratum conyzoides Linn. was found to have a significant anti-inflammatory activity (12).

Biochemically wound healing process is promoted by active agents that compose aqueous and or alcohol herbal extracts and those components act synergistically. High water levels during gel formulation (fibrin sealants are gels) can increase the penetration of antibacterial compounds that diffuse into the test media (21).

For this study, we first made antibacterial tests on wounds microbial pathogens and the efficacity was dose-dependent. Then, the concentration of 250 $\mathrm{mg} / \mathrm{mL}$ of diluted extract in physiological serum was choose for its efficacity on inhibiting wounds microbial pathogens activity.

Instead of all these supposed and confirmed antibacterial and healthy properties of phytochemicals contained in our extract, clotting times profile has changed in presence of additional extract. The best and shortest clotting time obtained on extract diluted plasma, although prolonged, was $65 \pm 12.56$ minutes at $2 \mathrm{M}$ ( $20 \mathrm{mM}$ final concentration $)$ calcium. Comparing to not diluted plasma clotting time at the same calcium concentration $(\mathrm{CT}=22 \pm 3.81$ minutes) and to the lowerest clotting time obtained at the same plasma dilution ( $\mathrm{CT}=11 \pm 4.15$ minutes), clotting time of extract added plasma, is respectively 3 folds and six folds longer. Phytochemicals present in the extract clearly possess thrombin inhibitory properties.

The interest in enzyme inhibitors obtained from plants began in the 1940s (22). Bijak et al. (23) showed that plant extracts at concentrations of 5 and $50 \mu \mathrm{g} / \mathrm{mL}$ prolonged clotting time (APTT, PT, TT) 
and decreased the maximal velocity of fibrin polymerization in human plasma. Similar effects of plants of Asteraceae and Rosaceae families are demonstrated by Pawlaczyk et al (24), who showed that the extracts from 17 plants of Asteraceae and Rosaceae families prolonged APTT and PT of human plasma, when the concentrations of extracts were ( 0.1 - $12.5 \mathrm{mg} / \mathrm{mL}$ ). It is well noting that Ageratum conyzoides Linn. belongs to Asteraceae family and thrombin, belonging to the family of serine proteases, plays an incontestable role in the blood coagulation process (18).

Polyhydroxyflavones, oligohydroxy and oligomethoxyflavones, flavanones, flavonols and methoxyflavones are all present in our extract (19). Though all their structures were not yet identified, on average $45 \%$ of molecules in this extract are polyhydroxyflavones. Chemically, we know that polyphenols action is in part due to their hydroxyl group linked protein, preventing enzymatic action. According to Liu and al. (8), eleven flavonoids were shown to produce dose-dependently inhibitory activities on thrombin. In fact, polyphenols interact with platelets proteins and inhibit thrombin. Almost $50 \%$ of triterpenes were identified in our extract (19) and we know terpenes also belong to enzymes inhibitors. Our extract contained proanthocyanidins and their monomers catechins (19). Flavonoids which inhibit thrombin amidolytic activity belong to flavanols, flavonols anthocyanins aglycones with $-\mathrm{OH}$ substituents at the position of R1 and R2 in the B-ring)-(18).

In addition, $\mathrm{Li}$ et al. had demonstrated the binding positions of six flavonoid compounds were alike with argatroban (25). It is worth mentioning that all of them located in the activity center and had interaction with the residue HIS57 or SER195, which indicated that these compounds likely had thrombin inhibitory activity (25). Serine proteinases activity is blocked through a tight binding of the enzyme active site and the inhibitor, resulting in a complex resistant to proteolysis (22). Human thrombin preference for small, planar flavonoids confirms the structural features of the restricted catalytic pocket of the enzyme (26). Clustering the docking conformations of thrombin-phenolic acid complexes, the result showed that their optimal conformation was not present in the activity center, meaning that phenolic acid compounds could bind with other places of the enzyme(25).
However, as we noted earlier, the clotting times profile when plant extract was added changed and at 4M calcium, among nine (9) samples only three (3) samples gelified, which are not statistically reliable. For higher calcium concentrations (6M and $8 \mathrm{M})$, no gelation occurred. We then hypothesize that those phytochemicals probably not potentiate calcium effect on antithrombin III but they rather have an additional effect on inhibition of thrombin by antithrombin III in presence of excess calcium leading to elongation of the clotting time (14). Then, the co-presence of high calcium concentration and our extract phytochemicals lead to a serious inhibition of thrombin resulting in no gelation during the 7200 seconds experimentation.

Wound dressings displaying antimicrobial activity started to be produced in order to surpass skin contamination and subsequent infections (27). Antimicrobial agents incorporated are antibiotics, nanoparticles and natural products.

\section{CONCLUSION}

This study is an original one which aimed to create a new fibrin sealant biomaterial combining the properties of a fibrin gel with antibacterial and analgesic properties of phytochemicals contained in an aqueous Ageratum Conyzoides Linn. leaves extract at a bactericide concentration. Our objective was difficult to achieve because of the thrombin inhibitory side effects of the extracts which were added to antithrombin inhibitory effects in presence of excess calcium; however, we do not fail at all since at $2 \mathrm{M}$ calcium concentration a clotting time was obtained.

We hardly supposed that our difficulties to obtain gelation provided from the stirring method used. In fact, when the solution (plasma + extract + calcium) are just mixed and homogenized, a gel occurred in few minutes. Evidently, they are weak gels. Some studies demonstrated a reversible inhibitory effect of flavonoids on serine proteases. Then we have to make deeper studies or change clotting time determination method to achieve this novel biomaterial.

\section{CONFLICT OF INTEREST}

The authors have not declared any conflict of interests. 


\section{ACKNOWLEDGEMENTS}

We would like to extend our gratitude to anonymous reviewers for their valuable comments and suggestions made to help improve the manuscript.

\section{REFERENCES}

1. Burnouf, T., Goubran, H.A., Chen, T.-M., Ou, K.-L., El-Ekiaby, M., Radosevic, M., 2013. Blood-derived biomaterials and platelet growth factors in regenerative medicine. Blood Reviews 27, 77-89.

2. Weisel, J.W., Litvinov, R.I., 2013. Mechanisms of fibrin polymerization and clinical implications. Blood 121, 1712-1719.

3. Sproul, E., Nandi, S., Brown, A., 2018. Fibrin biomaterials for tissue regeneration and repair, in: Peptides and Proteins as Biomaterials for Tissue Regeneration and Repair. Elsevier, pp. 151-173.

4. Janmey, P.A., Winer, J.P., Weisel, J.W., 2009. Fibrin gels and their clinical and bioengineering applications. Journal of The Royal Society Interface $6,1-10$.

5. Radosevich, M., Goubran, H.I., Burnouf, T., 1997. Fibrin sealant: scientific rationale, production methods, properties, and current clinical use. Vox Sang 72, 133-143.

6. Rybarczyk, B.J., 2003. Matrix-fibrinogen enhances wound closure by increasing both cell proliferation and migration. Blood 102, 4035-4043.

7. A Okwori, C Dina, S Junaid, I Okeke, J Adetunji, A Olabode, 2006. Antibacterial activities of Ageratum conyzoides extracts on selected bacterial pathogens. The Internet Journal of Microbiology 4, 1 .

8. Liu, L., Ma, H., Yang, N., Tang, Y., Guo, J., Tao, W., Duan, J., 2010. A Series of Natural Flavonoids as Thrombin Inhibitors: Structure-activity relationships. Thrombosis Research 126, e365-e378.

9. Khameneh, B., Iranshahy, M., Soheili, V., Fazly Bazzaz, B.S., 2019. Review on plant antimicrobials: a mechanistic viewpoint. Antimicrobial Resistance \& Infection Control 8, 118.

10. Ndip R. N., A. N. Ajonglefac, T. Wirna, H. N. Luma, C. Wirmum and S. M. N. Efange., 2009. In-vitro antimicrobial activity of Ageratum conyzoides (Linn) on clinical isolates of Helicobacter pylori. African Journal of Pharmacy and Pharmacology 3,11 pp. 585-592.

11. Singh S.B., Devi W.R., Devi W.I., Swapana N. and Singh C.B., 2013. Ethnobotany, phytochemistry and pharmacology of Ageratum conyzoides Linn
(Asteraceae). Journal of medicinal plant research 7,8 .

12. Tailor Chandra Shekhar, Goyal Anju, 2012. A Comprehensive Review on Ageratum conyzoides Linn. (Goat weed). International Journal of Pharmaceutical and Phytopharmacological Research 1,6.

13. Li, K., Diao, Y., Zhang, H., Wang, S., Zhang, Z., Yu, B., Huang, S., Yang, H., 2011. Tannin extracts from immature fruits of Terminalia chebula Fructus Retz. promote cutaneous wound healing in rats. BMC Complementary and Alternative Medicine 11, 86.

14. Akpalo A. Edefia, Douti F. Victoire, Layibo Yao, Feteke Lochina, Karou Simplice, 2020. Plasma fibrin sealant exclusively based on exogenous calcium and physiological thrombin: fitting and understanding of an old approach. Annals of Biomedical Sciences 19, 1 .

15. Miesbach, W., Schenk, J., Alesci, S., Lindhoff-Last, E., 2010. Comparison of the fibrinogen Clauss assay and the fibrinogen PT derived method in patients with dysfibrinogenemia. Thrombosis Research 126, e428-e433.

16. Shida, N., Kurasawa, R., Maki, Y., Toyama, Y., Dobashi, T., Yamamoto, T., 2016. Study of plasma coagulation induced by contact with calcium chloride solution. Soft Matter 12, 9471-9476.

17. Stabenfeldt, S.E., Gourley, M., Krishnan, L., Hoying, J.B., Barker, T.H., 2012. Engineering fibrin polymers through engagement of alternative polymerization mechanisms. Biomaterials 33, 535-544.

18. Bijak, M., Ziewiecki, R., Saluk, J., Ponczek, M., Pawlaczyk, I., Krotkiewski, H., Wachowicz, B., Nowak, P., 2014. Thrombin inhibitory activity of some polyphenolic compounds. Med Chem Res 23, 2324-2337.

19. Akpalo A. Edefia, Saloufou I. Kouassi, Eloh Kodjo and Kpegba Kafui, 2020. Wound healing biomolecules present in four proposed soft aqueous extractions of Ageratum conyzoides Linn. International Journal of Biological and Chemical Sciences 14, 2.

20. Arif Budiman, Alfia Nur Azizah, Insan Sunan K, 2018. Antibacterial activity of Ageratum conyzoides L. Extract in gel dosage forms against Staphylococcus epidermidis and Propionibacterium Acne. Journal of Pharmacy Research 12, 584-588.

21. Kaur Navpreet, Chaudhary Jasmine, Jain Akash and Kishore Lalit, 2011. Stigmasterol: a comprehensive review. International Journal of Pharmaceutical 
Sciences and Research IJPSR 2, 9: 2259-2265

22. Oliva, M.L.V., Sampaio, M.U., 2009. Action of plant proteinase inhibitors on enzymes of physiopathological importance. An. Acad. Bras. Cienc 81,615-621.

23. Bijak, M., Bobrowski, M., Borowiecka, M., Podsędek, A., Golański, J., Nowak, P., 2011. Anticoagulant effect of polyphenols-rich extracts from black chokeberry and grape seeds. Fitoterapia 82, 811-817.

24. Pawlaczyk, I., Czerchawski, L., Pilecki, W., LamerZarawska, E., Gancarz, R., 2009. Polyphenolicpolysaccharide compounds from selected medicinal plants of Asteraceae and Rosaceae families: Chemical characterization and blood anticoagulant activity. Carbohydrate Polymers 77, 568-575.
25. Li, Q.-Q., Yang, Y.-X., Qv, J.-W., Hu, G., Hu, Y.-J., Xia, Z.-N., Yang, F.-Q., 2018. Investigation of Interactions between Thrombin and Ten Phenolic Compounds by Affinity Capillary Electrophoresis and Molecular Docking. Journal of Analytical Methods in Chemistry 2018, 1-8.

26. Mozzicafreddo, M., Cuccioloni, M., Eleuteri, A.M., Fioretti, E., Angeletti, M., 2006. Flavonoids inhibit the amidolytic activity of human thrombin. Biochimie 88, 1297-1306.

27. D. Simoes, S.P. Miguel, M.P. Ribeiro, P. Coutinho, A.G. Mendonça, I.J. Correia, 2018. Recent advances on antimicrobial wound dressing: A review. European Journal of Pharmaeutis and Biopharmaceuticss 127, 130-141 